\title{
Expectations of stakeholders on the information disclosure from the Malaysian State Islamic Religious Councils (SIRCs) reporting
}

\author{
Rosnia Masruki*, Khaled Hussainey** and Doaa Aly***
}

\begin{abstract}
A good report should satisfy the expectations of the users based on their need of information. The present study views the users as a wide range of stakeholder groups as the concerned under the banner of public accountability, in which it explicates the right of the public to information about public sector organisations in discharging their accountability. Due to this, public managers are accountable to provide satisfactory information to the public for their actions and inactions to prevent any sanctions. SIRCs are not exempt. This study aims to identify the stakeholders' expectations of information disclosure from the SIRCs annual reports by conducting an online questionnaire survey. Such annual reports consist of financial and non-financial information, the fact that the annual report is the only single document that can provide information comprehensively about the reporting entity as that commonly practiced among the companies. The findings reveal that both financial and non-financial information disclosure are important. External stakeholders expected more information from the SIRCs' annual reports than SIRCs themselves. However, on average there is no significant difference in the responses of the disclosure items between internal and external stakeholders. But, there is significant difference across the six sub-stakeholder groups. Strategic information is the only information category significantly different. Nevertheless, comparing means for each of the disclosure item in every category of information, it infers several significant differences in their information expectations. As such, this study can be an avenue for future development of reporting framework to fairly satisfy the expectations of multiple stakeholders specifically for SIRCs in Malaysia yet it might be useful also for other not-for-profit (NPO), charities, religious bodies and public sectors in other countries.
\end{abstract}

JEL Codes: M41, M48, H75 and H83

\section{Introduction}

In the public sector realm, national economic activity, owned and controlled by the government are to provide public services for probity, compliance and control (Broadbent \& Guthrie 1992). Nevertheless, several pressures of social, economic and technological are forcing government to become more accountable for the use of publicly generated funds (Hoque \& Moll 2001). Due to this, Horner et al. (2006) claim that it is crucial to respond to the problems of old public administration and the lack of responsiveness to public needs. The public has undergone a paradigm shift to the global paradigm in management, which aims to achieve the organisations' accountability and promote efficiency and effectiveness.

\footnotetext{
${ }^{*}$ Rosnia Masruki, Faculty of Economics and Mualamat, Universiti Sains Islam Malaysia, Malaysia.

Email: rosnia@usim.edu.my

**Prof Khaled Hussainey, Portsmouth Business School, University of Portsmouth, United Kingdom.

Email: khaled.hussainey@port.ac.uk

${ }^{* * *}$ Dr Doaa Aly, Faculty of Business, Education and Professional Studies, University of Gloucestershire, United Kingdom and Faculty of Commerce, Helwan University, Egypt. Email:daly@glos.ac.uk
} 
Due to this greater accountability, public managers are empowered with high flexibility as posits in the New Public Management (NPM) in their management to enhance performance accountability beyond fiscal compliance. The public managers are accountable to provide satisfactory explanations within the public accountability to the public for their actions and inactions to prevent any sanctions (Romzek 2000). NPM indeed, became the dominant practice in Britain, Canada, New Zealand and some other developing countries towards improving public service performance through the efficiency of resource usage and quality in delivering services. Malaysia is one of the developing countries and State Islamic Religious Councils (SIRCs) is examined here to investigate the reporting practices for the discharge of accountability.

SIRCs in Malaysia were established under the purview of respective state enactments in an Islamic setting. SIRCs are chaired by State Rulers in each state since a Ruler is the head of the Islamic religion. They are responsible for any Islamic affairs as provided in the Article 74 of the Malaysian Federal Constitution which grants every state the right to interpret Islamic law (Shariah). Indeed, the management and administration of matters related to Muslim wealth derived from religious endowments (waqaf), alms (zakat) and treasury (mal or inheritance) for social welfare are independently conducted by the SIRCs in each state. This political system and cultural values, dominated by ethnic identity has influenced the global public sector reform (Haque 2007).

There have been a limited number of studies on the information disclosure of SIRCs. The majority of which were examined on waqaf in SIRCs; for instance (Siraj 2012; Yaacob \& Nahar 2011; Hisham 2006; Siti-Rokyah 2005; Abdul-Rahman \& Goddard 1998) with the exception of Abdul-Rahman \& Goddard (2003) and Abdul-Rahman (1999). This is probably due to the fact that waqaf is the oldest form of charity institution in Islamic history in which zakat (alms) centres for collection and distribution, Islamic boarding schools and religious charity bodies are eventually reinvented from the Islamic history of waqaf institutions (Afifuddin \& Siti-Nabiha 2010). This might explain why the growing number of studies on waqaf nowadays is to cope with the tremendous establishment of such organisations. To date, there is a lack of study examining annual report disclosure of SIRCs although it has been claimed that annual report is a very important tool to discharge accountability of SIRCs and to disseminate performance information to external parties such as overseeing bodies, media, beneficiaries and more importantly, potential contributors (Siraj 2012). This triggers the present paper to discuss the needs of information disclosure in the SIRCs annual report sought by the stakeholders and the importance of each item to discharge the SIRCs' accountability.

This study could be of interest to management of SIRCs, policy makers and the public at large on what stakeholders require from the SIRCs annual reports to inform accountability. The remainder of this paper is structured as follows; it discusses the review of literature and followed by the research methodology and the development of theoretical framework. Furthermore, the findings section is presented and this paper ends with summary and conclusions.

\section{Literature Review}

There were a number of negative cases reported in the local media about SIRCs's accountability (Berita Harian, 2 March 2011; Berita Harian, 27 November 2011; My Metro, 1 November 2011; The Sun, Daily 24 November 2011 and The Sun Daily, 24 April 2010). 
One of the dissatisfactions was due to the lack of dissemination of information in relation to the public money distribution (Wahid et al., 2009). The public nowadays are voicing demands for transparency from the SIRCs. They have shifted from being passive to more critical on their right to information about the activities and programs for public beneficiaries of SIRCs funds. In response to these criticisms, greater transparency would enable the public to make an informed judgement on the accountability of SIRCs. The content of the annual report in the overall accountability of SIRCs is thus essential.

A statutory financial statement is submitted to the Malaysian Auditor General (AG) which extends the accountability chain on a regular basis to each SIRC. The AG should then submit the audit report to the Ruler where it will be presented before the respective State Legislative Assembly and finally be passed to parliament. Nevertheless, other reports beyond the financial statement are also crucial to the SIRCs as they are held accountable for compliance with spending mandates and performance (Gray \& Jenkins 1993). This has called for an increased need for a comprehensive annual report beyond the mandated financial statements for the discharge of accountability among the SIRCs.

Hyndman (1990) suggests that providing satisfactory information to fulfil the needs of information users is very important in preparing the external report; specifically who is the most obvious and crucial user known as resource providers (FASB, 1980) as they are the primary fund resources of the organisations yet to receive any direct economic benefits. In return, it is prudent for them to know about their funds contributed to the organisation. In the context of SIRCs, resource providers can be defined as zakat payers (zakat collection contributes more than three quarter of the SIRCs' total fund) and donors in the forms of monetary or non-monetary such as endowed land, building and other tangible properties.

The importance of comprehensive report (others call it as performance reporting) which consists of financial and non-financial information has been highlighted by Hooks et al. (2012). Government performance reporting to the public is essential as a medium to show the transparency and accountability of the government (Grosso \& Van Ryzin, 2012). This may also enhance the confidence of the stakeholders through the activities and programs being reported as well as the entire organisation (Lee 2004). Notably, in the public sector such reporting helps to know how public money is managed to compare and evaluate the programs and activities undertaken by the reporting entities. Moreover, it is also useful to explain their accountability to a wide range of stakeholders, particularly to fund providers in making contribution decisions (Hyndman \& Anderson, 1995). Despite the broad range of stakeholders, identification of content of disclosure information sought by the stakeholders is often a debatable subject and has been examined in several studies (e.g. Hyndman, 1990; Dhanani \& Connolly, 2012; Abu Bakar and Saleh, 2011; Tooley et al., 2010).

Hyndman (1990) found that although four routine elements of information such as audited reporting statement, audited balance sheet, list of officers and audited cash flow statement are available in the NPOs' reports, but they are least needed by the contributors. Dhanani and Connolly (2012) revealed that reporting accountability practices are eventually motivated by a desire to legitimise their activities rather than the needs of stakeholders. Tooley et al. (2010) were concerned by performance reporting and they discovered that in addition to financial information, stakeholders perceive non-financial performance and future oriented information as important, these include output and outcome measures, customer satisfaction and impact measures, operating results and efficiency and effectiveness indicators. In this study the measurement of performance and indicators are beyond scope, rather it is concerned with the comprehensive content of annual report. 
The findings of these studies are inconclusive on the typical disclosure of information. However, most of the disclosure items used similar information disclosure although they used different basis of disclosure references and theories. For instance, Dhanani \& Connolly (2012) emphasised the stakeholder theory whereas Abu Bakar and Saleh (2011) used the accountability framework. The former used Statement of Reporting Practice (SORP) for charities in the UK categories whereas the latter used its national circular. Similar items found include aims and objectives, activities, program outcome, efficiency, financial position and staff. This paper attempts to fill in the gaps on the entire reporting, not just waqaf reporting, for SIRCs due to the unique nature of these organisations. This is crucial in order to increase the confidence of stakeholders through the comprehensive disclosure of information to explain their accountability. As such, it triggers the present research question, which is: what are the expectations of information disclosure in the SIRCs' annual reports to discharge their accountability?

\section{The Methodology and Theoretical Framework}

Research methodology; the present study is an exploratory using a questionnaire survey on the perceptions of stakeholders on the expected information which should be reported in the SIRCs' annual reports. This is an online questionnaire which was carried out in January to March 2015 via email through Corporate Communication Executive (CCE) of the population of SIRCs throughout Malaysia. The CCE was contacted to forward 100 questionnaires comprising 40:60; internal and external stakeholders which will make up a total of 1400 . The former consists of top officials, management and support staff in the SIRCs whereas the latter is regulators, creditors and the public at large.

This might be more due to the snowballing sampling. The researcher used personal contact to approach other respondents through email and text messages via online social media to respondents to redirect them to the online survey. Such wide coverage and fast media are crucial for data collection to increase responses and speed-up the data collection process. The respondents were selected based on their identifiable relationship with the SIRCs, emphasising the stakeholders' perspectives. As such, a cross-group comparison between the internal and external stakeholders can be performed so that major differences between the powerful and disadvantaged stakeholders can be determined as posits in disclosure theories. A $36 \%$ of responses were obtained which comprising of internal and external; 34:66 altogether. The distribution of the responses rate is presented in Table 1.

Table 1: Number of response

\begin{tabular}{llll}
\hline Type & Sub-group & $\mathbf{N}$ & $\mathbf{\%}$ \\
\hline \multirow{3}{*}{ Internal stakeholders } & Top officials & 60 & 11.3 \\
& Management & 81 & 15.2 \\
& Support staff & 39 & 7.3 \\
& Sub-total & $\mathbf{1 8 0}$ & $\mathbf{3 4}$ \\
External stakeholders & The public & 236 & 44.3 \\
& Oversight bodies & 74 & 13.9 \\
& Creditors & 43 & 8.1 \\
\hline Total & Subtotal & $\mathbf{3 5 3}$ & $\mathbf{6 6}$ \\
\hline
\end{tabular}


Based on Table 1, the respondents were categorised into either as internal or external stakeholders (Steccolini, 2004). There were 180 of the respondents were internal stakeholders and 353 were external stakeholders representing a proportion of 34:66. This is approximately similar to the targeted responses of 40:60. Each sub-group in the category has small sample and non-parametric test is pertinent which highlights the limitation in this study.

The questionnaires consisted of 57 disclosure items that based on related literature reviewed and various regulatory frameworks national and international such as Malaysian Government Treasury Circulars 4/2007 (Guidelines for preparing annual report for statutory bodies), SORP 2005 (Statement of Reporting Practices for UK charity bodies, FRS (Financial Reporting Standards) and IPSA (International Public Sector Accounting Standards).

A five-point Likert scale was used to identify the level of importance of each item of disclosure which is valued as $1=$ not important and should not be disclosed and $2=$ less important, 3=quite important, $4=$ very important and $5=$ extremely important should be disclosed in the SIRCs annual reports. Under the purview of public accountability, every citizen has right to the information of SIRCs. The questionnaire survey aims to identify the types of disclosure information and their level of importance; however respondents also can provide suggestion of additional disclosure items for each of the information category.

A mean was used for descriptive statistics for skewed distributions to derive at central tendency, Mann-Whitney (M-W) was employed to examine any significant difference between internal and external stakeholders' perspectives and further analysis used Kruskal-Wallis (K-W) to show if there is significant difference in the means of the response by the sub-categories in the stakeholder groups for each disclosure item.

Theoretical framework; the present study underlies the accountability theory and the stakeholder theory. The accountability theory provides a clear direction for this study; understanding could be reached to whom accountability is due and why accountability is required. As SIRCs are religious organisations, Mohamed Ibrahim (2000) highlights that Islam classifies dual accountability that explains main and second accountability. The former is accountability to God (Allah) and the latter refers to accountability to individual or organisation. Gray \& Jenkins (1993) define two types of obligations here; namely taking responsibility for actions (accountor - taking actions) and explaining such actions (accountee - requiring actions).

In the case of SIRCs, after considering God, SIRCs are the accountors, whereas the accountees are those who have a right to the explanation of the conduct such as internal and external stakeholders. This study views internal stakeholders are top officials, management and support staff whereas external stakeholders include overseeing bodies, creditors of SIRCs and the public - Malaysian Muslims at large as the entire Muslim community is subjected to the Islamic jurisdictions issued by the SIRCs. The present study views all of them as the focus 'to whom accountability is due' while in response to 'why' they have right to the information about SIRCs within the purview of public accountability. As such, accountability discharge through reporting (Coy et al., 2001; Hyndman \& Anderson, 1995; Yasmin et al., 2014) is crucial and may influence their perceptions about the reporting entities (Hyndman, 1991; Dhanani \& Connolly, 2012). 
A number of definitions on accountability concept using stakeholder theory have been discussed widely. Freeman (1984) describes stakeholders as internal or external groups or individuals who can influence and be influenced by the achievement of the organisations' objectives. Internal stakeholders can be easily identified compared to external stakeholders as internal people have a direct relationship as a result of the organisation's activities. Brammer \& Millington (2004) identify three groups of stakeholders broadly who may have a significant impact on three aspects; i) legislative and political; ii) community and consumers and iii) financial impact. The scope of this study suggests a wide range of stakeholders as the main concern for the purpose of discharging accountability of SIRCs as the sole trustees of Muslims wealth. Thus, based on both accountability and stakeholder theory, the accountability model for this study is illustrated in Figure 1 below.

Figure 1: Accountability model for SIRCs

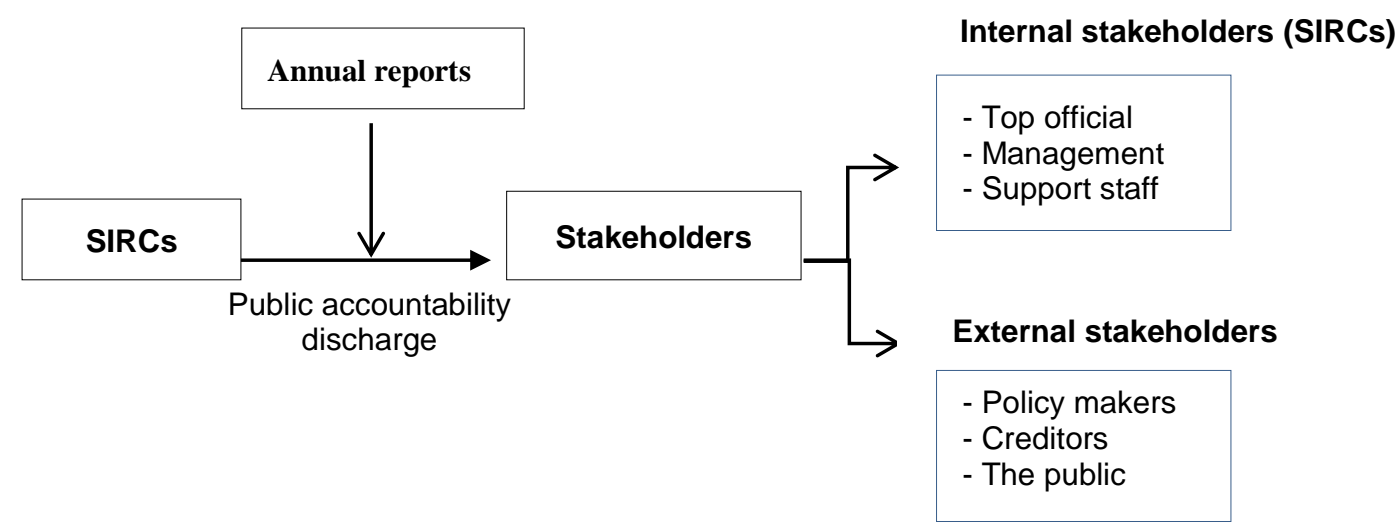

Figure 1 demonstrates that accountability of SIRCs (main accountability is embedded). This study focuses on the second accountability. The SIRCs are held accountable to the wide range of stakeholders; internal and external. The former refers to SIRCs themselves comprising top officials, management team and support staff whereas the latter includes policy makers, creditors and the public (funders, recipients, local community). The stakeholder theory suggests that the needs of stakeholders should be satisfied in the reporting to better discharge the accountability of reporting entities. This study views such reporting refers to annual reports which consist of reporting beyond the mandatory financial statements, indeed the non-financial information should be considered; these include background, strategic and fiduciary information, performance, activities and importantly, how efficiently the distribution of funds is carried out (Heijden, 2013; Khumawala et al.,2003; Wahab \& Abdul-Rahman, 2011).

\section{The Findings}

The self-developed 57 disclosure items which were tested in the questionnaire are subgrouped into five categories of information, namely: corporate information (7), strategic information (5), financial performance (9), non-financial performance (8) and financial statements (28). 
Table 2: Descriptive statistics and means by category of information

\begin{tabular}{lllllllll}
\multirow{2}{*}{ No. } & \multirow{2}{*}{ Information category } & \multirow{2}{*}{ Min } & \multirow{2}{*}{ Max } & \multirow{2}{*}{ SD } & \multicolumn{2}{c}{ Mean scores } & \multicolumn{2}{c}{ p-value } \\
\cline { 6 - 8 } & & 1.29 & 5.00 & 0.65 & 4.01 & 4.03 & 4.02 & 0.765 \\
2.0 & Corporate information (7) & 1.00 & 5.00 & 0.62 & 4.16 & 4.24 & 4.21 & 0.116 \\
2.0 & Strategic information (5) & 2.00 & 5.00 & 0.60 & 4.12 & 4.20 & 4.17 & 0.268 \\
3.0 & Financial performance (9) & 1.88 & 5.00 & 0.61 & 4.06 & 4.16 & 4.13 & 0.095 \\
4.0 & Non-financial performance (8) & 2.64 & 5.00 & 0.58 & 4.19 & 4.23 & 4.22 & 0.686 \\
5.0 & Financial statements (28) & 2.74 & 5.00 & 0.52 & 4.13 & 4.19 & 4.17 & 0.456 \\
\hline & Overall mean & &
\end{tabular}

${ }^{*}$ Numbers in brackets are the number of disclosure items for each category of information.

${ }^{* *} A$ mean score of 1 indicates the disclosure item was perceived as not important and should not be disclosed whereas score $2=$ less important, 3=quite important, 4=very important, 5 extremely important and should be disclosed in the SIRCs' annual reports.

Table 2 summarises information disclosure by information category. Both groups of stakeholders perceived each category of the information to be very important (mean=4.17) and external stakeholders (mean=4.19) were more likely to expect more information than internal (mean=4.13). But, statistically, there were no significant differences between the internal and external stakeholders ( $p$-value=0.456) and in fact, the mean scores were similar, ranging from 4.01-4.24.

Each information category was further analysed according to sub-stakeholder groups to assure in-depth and robust analysis. Specifically, to identify the importance level for each disclosure item as perceived by various groups of stakeholders. Similar to the previous analysis, the mean scores for each sub-group of stakeholder were computed and a $p$ value for each item was calculated to examine whether there was any statistically significant difference between the means. Two types of non-parametric test were used: firstly, a Mann-Whitney (M-W) test examined significant differences between the internal and external stakeholder groups; secondly, a Kruskal-Wallis (K-W) test by stakeholder sub-group of six types of stakeholders was carried out. Starting from the first category of information, i.e. corporate information, Table 3 shows its mean scores and variances.

Table 3: Mean scores and variance analysis for corporate information

\begin{tabular}{|c|c|c|c|c|c|c|c|c|c|c|c|c|}
\hline \multirow{2}{*}{ No. } & \multirow{2}{*}{ Disclosure items } & \multicolumn{3}{|c|}{ Mean } & \multirow{2}{*}{$\begin{array}{l}\text { M-W } \\
\text { p-value }\end{array}$} & \multicolumn{6}{|c|}{ Mean } & \multirow{2}{*}{$\begin{array}{l}\text { K-W } \\
\text { p-value }\end{array}$} \\
\hline & & Int & Ext & Both & & Top & Mgt & Supp & Reg & Pub & Cred & \\
\hline 1.1 & Establishment and operation & 4.24 & 4.27 & 4.26 & 0.668 & 4.32 & 4.28 & 4.05 & 4.23 & 4.29 & 4.26 & 0.464 \\
\hline 1.2 & Objectives & 4.03 & 4.11 & 4.08 & 0.403 & 4.28 & 4.00 & 3.72 & 4.18 & 4.10 & 4.05 & $0.014^{*}$ \\
\hline 1.3 & Organisational structure & 4.06 & 4.06 & 4.06 & 0.893 & 4.25 & 4.05 & 3.77 & 4.18 & 4.04 & 3.98 & $0.048^{\star}$ \\
\hline 1.4 & Board of directors & 4.11 & 4.06 & 4.08 & 0.617 & 4.30 & 4.02 & 3.97 & 4.14 & 4.04 & 4.07 & 0.304 \\
\hline 1.5 & Ethical operational policies & 4.13 & 4.21 & 4.18 & 0.251 & 4.25 & 4.15 & 3.90 & 4.20 & 4.22 & 4.16 & 0.257 \\
\hline 1.6 & Personnel & 3.68 & 3.71 & 3.70 & 0.685 & 3.75 & 3.62 & 3.72 & 3.65 & 3.73 & 3.65 & 0.874 \\
\hline \multirow[t]{2}{*}{1.7} & Personnel development & 3.79 & 3.76 & 3.77 & 0.934 & 3.85 & 3.69 & 3.90 & 3.81 & 3.75 & 3.72 & 0.664 \\
\hline & Sub-score & 4.01 & 4.03 & 4.02 & 0.765 & 4.14 & 3.97 & 3.86 & 4.05 & 4.02 & 3.98 & 0.355 \\
\hline
\end{tabular}

Int=Internal, Ext=External, Top=Top officials, Mgt=Management, Supp=Support Staff, Reg=Regulators, Pub=Public, Cred=Creditors

${ }^{* *}$ significant at $5 \%$

On average, both groups of stakeholders regarded item 1.1 (mean=4.26) as the most important corporate information. External stakeholders (mean=4.03) were slightly more concerned with corporate information than internal (mean=4.01), however this was a very small difference and statistically, no significant difference ( $p$-value=0.765). All stakeholders regarded items 1.6 and 1.7 (mean=3.70 and 3.77) as quite important (similar to Hooks et al., 2012) while other items were regarded as being very important. However, amongst the sub-stakeholders most of the items were viewed as quite important by support staff, except item 1.1. The sub-group of creditors agreed with them with regard to items $1.3,1.6$ and 1.7. Although the sub-group top officials produced the highest mean (4.14) with regard 
to the importance of corporate information while support staff produced the lowest (mean=3.86), there were no statistically significant differences for the majority of disclosure items across sub-stakeholders except for items 1.2 and 1.3. This supports the consensus that different users may have varying information needs (Belkoui, 2004). For example, support staff regarded only one item of corporate information as being very important while the rest of the six items were quite important. By contrast, creditors viewed three of the items as being quite important while the rest were viewed as very important.

The second category was strategic information, statistics for which are shown in Table 4. Similar to the previous category, external stakeholders (mean=4.24) were more interested in strategic information than internal stakeholders (mean=4.16). Item 2.2 was regarded as the most important information item overall (mean=4.40), and the one which top officials ranked as the most important (mean=4.45). This implies that top officials were very interested in the performance of SIRCs. Despite the high overall weighted importance, most stakeholders rated item 2.1 as quite important (mean=3.67-3.94) except top officials (mean=4.20) and regulators (4.04). Both top officials and regulators are powerful stakeholders as compared to other stakeholders; both groups perceived the chairman's statement to be very important in the SIRCs' annual reports and that the chairman's achievement should be portrayed in the chairman's report. Item 2.4 was another quite important item ranked by internal stakeholders (management and support staff) and external (creditors), probably because government grants are not very relevant to them because the money is entrusted to the SIRCs; however, top officials, regulators and the public were more interested in knowing about it. This might provide a signal on how efficiently the SIRCs manage such funds. Other items in strategic information were regarded as very important.

There were statistical significant differences between internal and external groups in items 2.3 and 2.4. The relevance of both items influenced the respondents in their ratings. For instance, item 2.3 (mean=4.35) was viewed very important by the external stakeholders compared with internal (mean=4.21) especially the public (mean=4.36), indicating that they would like to be provided with a summary of the whole achievement of SIRCs. Such a summary might be better understood by the public at large but it would entail a lot of additional work to the SIRCs in preparing the report. Due to the obvious different needs, items 2.1 and 2.4 were the only statistically significant differences across the substakeholder groups for this category. Overall, strategic information was the only significant information category among other informational categories. The results suggest that powerful and less advantaged stakeholders have different information expectations, as suggested in stakeholder theory. This calls for more disclosure studies focusing on the information expectation gaps in order to fairly satisfy these gaps.

Table 4: Mean Scores and variance analysis for strategic information

\begin{tabular}{|c|c|c|c|c|c|c|c|c|c|c|c|c|}
\hline \multirow{2}{*}{ No. } & \multirow{2}{*}{ Disclosure items } & \multicolumn{3}{|c|}{ Mean } & \multirow{2}{*}{$\begin{array}{l}\text { M-W } \\
p \text {-value }\end{array}$} & \multicolumn{6}{|c|}{ Mean } & \multirow{2}{*}{$\begin{array}{l}\text { K-W } \\
\text { p-value }\end{array}$} \\
\hline & & Int & Ext & Both & & Top & Mgt & Supp & Reg & Pub & Cred & \\
\hline 2.1 & Chairman report & 3.93 & 3.94 & 3.94 & 0.569 & 4.20 & 3.85 & 3.67 & 4.04 & 3.94 & 3.79 & $0.021^{*}$ \\
\hline 2.2 & $\begin{array}{l}\text { Performance } \\
\text { achievement }\end{array}$ & 4.39 & 4.40 & 4.40 & 0.884 & 4.45 & 4.36 & 4.36 & 4.42 & 4.42 & 4.26 & 0.848 \\
\hline 2.3 & Summary facts and figures & 4.21 & 4.35 & 4.30 & $0.019^{*}$ & 4.32 & 4.14 & 4.18 & 4.32 & 4.36 & 4.33 & 0.190 \\
\hline 2.4 & Government borrowing/grants & 3.97 & 4.15 & 4.09 & $0.015^{\star}$ & 4.17 & 3.88 & 3.87 & 4.16 & 4.19 & 3.86 & $0.006^{*}$ \\
\hline \multirow[t]{2}{*}{2.5} & Forward looking information & 4.28 & 4.35 & 4.33 & 0.392 & 4.42 & 4.23 & 4.18 & 4.38 & 4.38 & 4.14 & 0.194 \\
\hline & Sub-score for strategic info & 4.16 & 4.24 & 4.21 & 0.116 & 4.31 & 4.09 & 4.05 & 4.26 & 4.26 & 4.07 & $0.035^{\star}$ \\
\hline
\end{tabular}


The third category of disclosure item is financial performance as presented in Table 5 . In general, all financial performance items were ranked very important (mean=4.17) except item 3.7 (mean=3.99) which was regarded quite important but only by a small amount. External stakeholders (mean=4.20) expected more financial performance information than internal (mean=4.12) and the internal perceived items 3.7 and 3.8 quite important. Both items ranked as quite important were efficiency measurements of income, which external stakeholders seem to attach more importance to (mean=4.06 and 4.10); however, this was less important to the SIRCs (mean=3.87 and 3.95). Statistically, there were significant differences in three items of efficiency measurements (items 3.7, 3.8 and 3.9) between internal and external stakeholders. This indicates that external stakeholders were more interested in financial performance in terms of efficiency ratios in comparison with members of SIRCs. Probably, this includes interpretation of the ratios so as to be meaningful information to various sub-groups of stakeholders (Sulaiman et al., 2009).

The highest mean across sub-stakeholders that was ranked by top officials (mean=4.47) was item 3.1, which shows the financial review as the most important item of financial performance. However, individual groups, particularly support staff, viewed almost half of them as quite important, such as items 3.2, 3.3, 3.7 and 3.8. Top officials regarded only item 3.7 as quite important, similar to management, who also ranked item 3.8 similarly. This shows that there was a conflict of expectation of information among the SIRCs' members which might influence their reporting in the annual reports. This indicates that lower levels of management were less likely to aware of the importance of performance reporting. On another issue, there were significant differences in items 3.2 and 3.3 across the sub-stakeholder groups. Both investment and actual to budget comparison was seen by support staff as being not very important and the latter item was similarly viewed by creditors, who preferred to know about the SIRCs' solvency rather than their investment.

Table 5: Mean scores and variance analysis for financial performance

\begin{tabular}{|c|c|c|c|c|c|c|c|c|c|c|c|c|}
\hline \multirow{2}{*}{ No. } & \multirow{2}{*}{ Disclosure items } & \multicolumn{3}{|l|}{ Mean } & \multirow{2}{*}{$\begin{array}{l}\text { M-W } \\
p \text {-value }\end{array}$} & \multicolumn{6}{|c|}{ Mean } & \multirow{2}{*}{$\begin{array}{l}\mathrm{K}-\mathrm{W} \\
\mathrm{p} \text {-value }\end{array}$} \\
\hline & & Int & Ext & Both & & Top & Mgt & Supp & Reg & Pub & Cred & \\
\hline 3.1 & Financial review & 4.38 & 4.41 & 4.40 & 0.878 & 4.47 & 4.35 & 4.31 & 4.43 & 4.42 & 4.30 & 0.684 \\
\hline 3.2 & Investment & 4.09 & 4.12 & 4.11 & 0.835 & 4.30 & 4.06 & 3.82 & 4.11 & 4.16 & 3.93 & $0.027 *$ \\
\hline 3.3 & Actual to budget comparison & 4.19 & 4.23 & 4.22 & 0.866 & 4.37 & 4.16 & 3.97 & 4.43 & 4.20 & 4.02 & $0.024 *$ \\
\hline 3.4 & Financial performance ratios & 4.20 & 4.20 & 4.20 & 0.922 & 4.33 & 4.19 & 4.03 & 4.27 & 4.20 & 4.09 & 0.194 \\
\hline 3.5 & $\begin{array}{l}\text { Administration to total } \\
\text { expenses }\end{array}$ & 4.14 & 4.20 & 4.18 & 0.385 & 4.20 & 4.11 & 4.13 & 4.26 & 4.22 & 4.02 & 0.450 \\
\hline 3.6 & $\begin{array}{l}\text { Program expenses/total } \\
\text { expenses }\end{array}$ & 4.13 & 4.20 & 4.17 & 0.363 & 4.12 & 4.10 & 4.23 & 4.14 & 4.23 & 4.12 & 0.705 \\
\hline 3.7 & $\begin{array}{l}\text { Net rental income and } \\
\text { expenses/rental income }\end{array}$ & 3.87 & 4.06 & 3.99 & $0.005^{*}$ & 3.97 & 3.83 & 3.79 & 4.07 & 4.05 & 4.12 & 0.07 \\
\hline 3.8 & $\begin{array}{l}\text { Investment income/average } \\
\text { investment }\end{array}$ & 3.95 & 4.10 & 4.05 & $0.044 *$ & 4.12 & 3.88 & 3.85 & 4.11 & 4.11 & 4.00 & 0.088 \\
\hline \multirow[t]{2}{*}{3.9} & $\begin{array}{l}\text { Expenditure by } \\
\text { activities/income by activities }\end{array}$ & 4.11 & 4.25 & 4.20 & $0.047 *$ & 4.13 & 4.07 & 4.13 & 4.27 & 4.25 & 4.19 & 0.471 \\
\hline & $\begin{array}{l}\text { Sub-score for financial } \\
\text { performance }\end{array}$ & 4.12 & 4.20 & 4.17 & 0.268 & 4.22 & 4.08 & 4.03 & 4.23 & 4.20 & 4.09 & 0.152 \\
\hline
\end{tabular}

The fourth category was non-financial performance and its results are reported in Table 6. On average, both internal and external stakeholders regarded non-financial items as very important (mean=4.13), in which external (mean=4.16) were more likely to expect nonfinancial performance information compared to internal stakeholders (mean=4.06). In particular SIRCs viewed item 4.7 (mean=3.99) as quite important. A few Items (4.6, 4.7 and 4.8; effectiveness, productivity and customer satisfaction respectively) in performance 
reporting were statistically significant differences between internal and external stakeholders.

In comparing the information expectations across sub-stakeholders, support staff (mean=3.97) ranked most items as quite important and this includes items 4.1, 4.4, 4.6 and 4.7. The management supported their view of items 4.6 and 4.7 in addition to item 4.2, whereas for creditors, it was item 4.7. This reveals that productivity measure were not favourable to support staff and management in SIRCs and creditors. The lower awareness of the importance of productivity might influence the quality of services provided in SIRCs, which should be used as one of the performance indicators in SIRCs to discharge their accountability. The SIRCs' management also seems to have been less concerned with the reporting of the resources used, and this might lead to closer scrutiny of the fund's management in the local media. Regulators on the other hand, rated non-financial performance the highest (mean=4.24) and this was roughly similar to top officials and creditors (mean=4.15-4.20). Both are powerful stakeholders who wanted to know about information such as the effectiveness, efficiency and productivity of SIRCs for improvement and decision making. The demand for such information was statically significant different between internal and external stakeholders in items 4.6, 4.7 and 4.8, whereas within the six stakeholder groups, there were significant differences in items 4.1, 4.4 and 4.5. There were statistically significant differences in items $4.1,4.4$ and 4.5 (performance target, outcome and efficiency) between internal and external. It is quite challenging for SIRCs to decide on the appropriate reported non-financial performance as various stakeholders have different expectations. However, they attach great importance to the reporting of non-financial performance as a whole.

Table 6: Mean Scores and variance analysis for non-financial performance

\begin{tabular}{|c|c|c|c|c|c|c|c|c|c|c|c|c|}
\hline \multirow{2}{*}{ No. } & \multirow{2}{*}{ Disclosure items } & \multicolumn{3}{|c|}{ Mean } & \multirow{2}{*}{$\begin{array}{l}\text { M-W } \\
\text { p-value }\end{array}$} & \multicolumn{6}{|c|}{ Mean } & \multirow{2}{*}{$\begin{array}{c}\mathrm{K}-\mathrm{W} \\
\text { p-value }\end{array}$} \\
\hline & & Int & Ext & Both & & Top & Mgt & Supp & Reg & Pub & Cred & \\
\hline 4.1 & $\begin{array}{l}\text { Performance target and } \\
\text { objectives }\end{array}$ & 4.03 & 4.18 & 4.13 & 0.068 & 4.18 & 4.06 & 3.74 & 4.27 & 4.15 & 4.16 & $0.028^{*}$ \\
\hline 4.2 & Input & 4.01 & 4.12 & 4.08 & 0.141 & 4.05 & 3.98 & 4.03 & 4.15 & 4.08 & 4.26 & 0.439 \\
\hline 4.3 & Output & 4.15 & 4.19 & 4.17 & 0.561 & 4.18 & 4.14 & 4.13 & 4.24 & 4.14 & 4.35 & 0.502 \\
\hline 4.4 & Outcome & 4.06 & 4.17 & 4.13 & 0.091 & 4.17 & 4.07 & 3.85 & 4.34 & 4.11 & 4.21 & $0.022 *$ \\
\hline 4.5 & Efficiency & 4.15 & 4.13 & 4.14 & 0.722 & 4.15 & 4.16 & 4.13 & 4.38 & 4.05 & 4.16 & $0.029 *$ \\
\hline 4.6 & Effectiveness & 4.01 & 4.14 & 4.10 & $0.046^{*}$ & 4.13 & 3.94 & 3.95 & 4.22 & 4.12 & 4.14 & 0.214 \\
\hline 4.7 & Productivity measures & 3.99 & 4.14 & 4.09 & $0.035^{*}$ & 4.08 & 3.95 & 3.92 & 4.26 & 4.14 & 3.98 & 0.120 \\
\hline \multirow[t]{2}{*}{4.8} & $\begin{array}{l}\text { Customers satisfaction } \\
\text { measures }\end{array}$ & 4.08 & 4.21 & 4.17 & $0.041 *$ & 4.22 & 4.00 & 4.03 & 4.11 & 4.22 & 4.35 & 0.132 \\
\hline & $\begin{array}{l}\text { Sub-score for non- } \\
\text { financial }\end{array}$ & 4.06 & 4.16 & 4.13 & 0.095 & 4.15 & 4.04 & 3.97 & 4.24 & 4.13 & 4.20 & 0.171 \\
\hline
\end{tabular}

The last category was financial statements, consisting of 28 items as shown in Table 7 . In terms of the overall mean, external stakeholders' mean (4.23) was higher than internal (mean=4.19), especially for the public (mean=4.24); however, this was a slightly lower mean as compared to top officials (mean=4.29). Probably, the public are interested to know about the collection and spending of funds by SIRCs to a similar extent as top officials as this represents their accountability to the public at large. A majority of the items were regarded as very important to both internal (except deferred liabilities and government credits) and external stakeholders and in fact there was no significant difference in all items. However, surprisingly SIRCs' management saw items 5.2 and 5.4 as quite important, similar to support staff. Besides that, the support staff perceived also nine items to be quite important, i.e. 5.3, 5.7, 5.8, 5.9, 5.14, 5.18, 5.22-5.24. Probably, this 
was due to a lack of awareness of these items due to their lack of knowledge about financial matters, which might have influenced such ratings. Creditors rated items 5.8 and 5.9 as quite important because they possibly wanted to know about the SIRCs' ability to pay their debts rather than the SIRCs' deferred liabilities. However statistically, only four items in the financial statements were significantly differently perceived by the substakeholders; these were item 5.3, 5.8, 5.9 and 5.22.

Table 7: Mean Scores and variance analysis for financial statements

\begin{tabular}{|c|c|c|c|c|c|c|c|c|c|c|c|c|}
\hline \multirow{2}{*}{ No. } & \multirow{2}{*}{ Disclosure items } & \multicolumn{3}{|c|}{ Mean } & \multirow{2}{*}{$\begin{array}{l}\text { M-W } \\
\text { p-value }\end{array}$} & \multicolumn{2}{|c|}{ Mean } & \multirow[b]{2}{*}{ Supp } & \multirow[b]{2}{*}{ Reg } & \multirow[b]{2}{*}{ Pub } & \multirow[b]{2}{*}{ Cred } & \multirow{2}{*}{$\begin{array}{l}\mathrm{K}-\mathrm{W} \\
\mathrm{p} \text {-value }\end{array}$} \\
\hline & & Int & Ext & Both & & Top & Mgt & & & & & \\
\hline$\overline{5.1}$ & Balance Sheet & 4.44 & 4.44 & 4.44 & 0.769 & 4.43 & 4.49 & 4.36 & 4.46 & 4.44 & 4.44 & 0.808 \\
\hline 5.2 & $\begin{array}{l}\text { Total Non-current assets at } \\
\text { cost }\end{array}$ & 4.01 & 4.14 & 4.10 & 0.060 & 4.15 & 3.95 & 3.90 & 4.15 & 4.14 & 4.19 & 0.209 \\
\hline 5.3 & Long-term investments & 4.15 & 4.21 & 4.19 & 0.465 & 4.37 & 4.11 & 3.90 & 4.18 & 4.24 & 4.09 & $0.048 *$ \\
\hline 5.4 & Long-term debtors & 4.02 & 4.12 & 4.08 & 0.167 & 4.20 & 3.99 & 3.79 & 4.12 & 4.11 & 4.19 & 0.101 \\
\hline 5.5 & Current assets & 4.32 & 4.32 & 4.32 & 0.770 & 4.45 & 4.26 & 4.23 & 4.34 & 4.29 & 4.42 & 0.379 \\
\hline 5.6 & Current liabilities & 4.32 & 4.29 & 4.30 & 0.838 & 4.43 & 4.30 & 4.21 & 4.34 & 4.29 & 4.23 & 0.613 \\
\hline 5.7 & Long-term liabilities & 4.18 & 4.17 & 4.17 & 0.995 & 4.35 & 4.17 & 3.92 & 4.19 & 4.19 & 4.02 & 0.135 \\
\hline 5.8 & Deferred liabilities & 3.99 & 4.08 & 4.05 & 0.237 & 4.13 & 4.04 & 3.67 & 4.15 & 4.10 & 3.81 & $0.038 *$ \\
\hline 5.9 & $\begin{array}{l}\text { Deferred credits from } \\
\text { government grants }\end{array}$ & 3.96 & 4.06 & 4.02 & 0.252 & 4.13 & 4.01 & 3.59 & 4.03 & 4.08 & 3.98 & $0.036^{*}$ \\
\hline 5.10 & Reserves & 4.13 & 4.21 & 4.18 & 0.336 & 4.27 & 4.05 & 4.08 & 4.07 & 4.23 & 4.35 & 0.113 \\
\hline 5.11 & Income Statement & 4.38 & 4.36 & 4.37 & 0.729 & 4.42 & 4.44 & 4.21 & 4.31 & 4.39 & 4.26 & 0.291 \\
\hline 5.12 & Revenue by source of funds & 4.23 & 4.26 & 4.25 & 0.781 & 4.33 & 4.23 & 4.08 & 4.16 & 4.28 & 4.33 & 0.334 \\
\hline 5.13 & Revenue by services rendered & 4.22 & 4.22 & 4.22 & 0.937 & 4.23 & 4.28 & 4.08 & 4.19 & 4.21 & 4.37 & 0.501 \\
\hline 5.14 & Other incoming revenue & 4.07 & 4.10 & 4.09 & 0.662 & 4.17 & 4.06 & 3.95 & 4.04 & 4.12 & 4.09 & 0.701 \\
\hline 5.15 & Total revenue & 4.27 & 4.34 & 4.32 & 0.435 & 4.38 & 4.28 & 4.08 & 4.30 & 4.35 & 4.35 & 0.347 \\
\hline 5.16 & Expenditure by services & 4.16 & 4.23 & 4.20 & 0.290 & 4.20 & 4.15 & 4.13 & 4.18 & 4.24 & 4.26 & 0.852 \\
\hline 5.17 & Expenditure by functions & 4.19 & 4.20 & 4.20 & 0.867 & 4.17 & 4.23 & 4.15 & 4.14 & 4.22 & 4.21 & 0.890 \\
\hline 5.18 & $\begin{array}{l}\text { Administration and } \\
\text { governance costs }\end{array}$ & 4.12 & 4.16 & 4.15 & 0.520 & 4.20 & 4.17 & 3.90 & 4.04 & 4.20 & 4.19 & 0.203 \\
\hline 5.19 & Total expenditure & 4.32 & 4.36 & 4.34 & 0.521 & 4.32 & 4.35 & 4.26 & 4.32 & 4.36 & 4.40 & 0.947 \\
\hline 5.20 & Other recognised gains/losses & 4.15 & 4.16 & 4.16 & 0.937 & 4.25 & 4.12 & 4.05 & 4.19 & 4.17 & 4.05 & 0.548 \\
\hline 5.21 & Surplus/deficit & 4.22 & 4.26 & 4.25 & 0.569 & 4.33 & 4.17 & 4.13 & 4.36 & 4.23 & 4.23 & 0.437 \\
\hline 5.22 & $\begin{array}{l}\text { Total fund brought forward } \\
\text { (bf) }\end{array}$ & 4.07 & 4.19 & 4.15 & 0.164 & 4.25 & 4.09 & 3.77 & 4.18 & 4.21 & 4.09 & $0.036^{*}$ \\
\hline 5.23 & $\begin{array}{l}\text { Total fund carried forward } \\
\text { (c/f) }\end{array}$ & 4.11 & 4.18 & 4.16 & 0.373 & 4.27 & 4.09 & 3.90 & 4.18 & 4.21 & 4.05 & 0.141 \\
\hline 5.24 & $\begin{array}{l}\text { Statement of Assets and } \\
\text { Liabilities }\end{array}$ & 4.13 & 4.15 & 4.14 & 0.829 & 4.30 & 4.15 & 3.85 & 4.16 & 4.17 & 4.00 & 0.161 \\
\hline 5.25 & Statement of cash flows & 4.36 & 4.35 & 4.35 & 0.838 & 4.40 & 4.36 & 4.28 & 4.36 & 4.35 & 4.33 & 0.961 \\
\hline 5.26 & Notes to the accounts & 4.16 & 4.25 & 4.22 & 0.233 & 4.23 & 4.15 & 4.08 & 4.26 & 4.24 & 4.30 & 0.608 \\
\hline 5.27 & Audit Certificate & 4.27 & 4.35 & 4.33 & 0.297 & 4.37 & 4.28 & 4.10 & 4.34 & 4.40 & 4.14 & 0.137 \\
\hline \multirow[t]{2}{*}{5.28} & Auditor index rating & 4.23 & 4.30 & 4.28 & 0.578 & 4.33 & 4.21 & 4.13 & 4.38 & 4.28 & 4.23 & 0.635 \\
\hline & $\begin{array}{l}\text { Sub-score for financial } \\
\text { statements }\end{array}$ & 4.19 & 4.23 & 4.22 & 0.686 & 4.29 & 4.19 & 4.03 & 4.22 & 4.24 & 4.20 & 0.297 \\
\hline
\end{tabular}

Based on the results provided in Table 2 to Table 7, a majority of the disclosure items (52 items, 91\%) were regarded as very important (means=4.00-4.44) whereas the remaining (5 items, 9\%) were viewed as quite important. The five quite important items (mean 3.693.98) were: deferred government credit; net income and expenses to rental income; chairman's report; personnel development; and personnel information. The results of an $\mathrm{M}-\mathrm{W}$ test of weighted importance for differences between pairs of stakeholder groups are presented in Table 8. 


\begin{tabular}{lllllll}
\hline & Top official & Management & Support staff & Regulators & Creditors & Public \\
\hline Top officials & N/A & 0.169 & $0.018^{*}$ & 0.445 & 0.311 & 0.203 \\
Management & & N/A & 0.234 & 0.443 & 0.402 & 0.998 \\
Support staff & & & N/A & 0.073 & $0.030^{*}$ & 0.320 \\
Regulators & & & & N/A & 0.957 & 0.440 \\
Creditors & & & & & N/A & 0.435 \\
Public & & & & & & N/A \\
\hline
\end{tabular}

$\mathrm{N} / \mathrm{A}=$ not applicable

*significant at $5 \%$

Statistically, there were two significant differences for all disclosure items; these were between: a) the support staff and top officials and b) support staff and creditors. This implies that within the internal stakeholders, less powerful (support staff) and more powerful (top officials) stakeholders had significantly different perspectives on the expectation of disclosure information from the SIRCs. Similarly, there were significant differences between internal and external stakeholders, in this case between support staff and creditors. This was probably due to these groups different interests in certain kinds of financial information; for example, creditors were more interested in items that gave information on solvency. In sum, the differences are ranked and similarities by category of information can be seen in Table 9.

Table 9: Ranking of mean differences and similarities according to the information category

\begin{tabular}{|c|c|c|c|c|c|c|c|}
\hline \multirow{2}{*}{ Category of information } & \multirow{2}{*}{$\mathrm{N}$} & \multicolumn{2}{|c|}{ No. of items showing significant difference } & \multicolumn{2}{|c|}{ Differences } & \multicolumn{2}{|c|}{ Similarities } \\
\hline & & Internal vs External & Sub-stakeholders & $\mathrm{N}$ & $\%$ & $\mathrm{~N}$ & $\%$ \\
\hline Non-financial performance & 8 & 3 & 3 & 6 & 75 & 2 & 25 \\
\hline Financial performance & 9 & 3 & 2 & 5 & 56 & 4 & 44 \\
\hline Financial statements & 28 & 0 & 4 & 4 & 14 & 24 & 86 \\
\hline Strategic information & 5 & 1.5 & 1.5 & 3 & 60 & 2 & 40 \\
\hline Corporate information & 7 & 0 & 2 & 2 & 29 & 5 & 71 \\
\hline Total & 57 & & & 20 & & 37 & \\
\hline
\end{tabular}

Non-financial performance was the category with the most significant differences between the stakeholders' views ( 6 items, $75 \%$ ), whereas the category with the least was corporate information (2 items, 29\%). This implies that the typical stakeholders were requesting different information beyond the financial matters for performance evaluation rather than just corporate information. Probably, they wanted to know the efficiency of the trusted funds, rather than corporate information of SIRCs which has already been made available and which the public is aware of. The financial statements were more likely to be seen similarly across the stakeholders as there are specific guidelines for preparing such mandatory financial statements. Other categories of information were more likely to be similar to each other. Therefore, the quality of comprehensive annual reports is a useful subject to explore in terms of the extent to which it meets the stakeholders' expectations within the umbrella of public accountability.

\section{Summary and Conclusions}


This paper aims to identify the expectations of a wide range of stakeholders on the disclosure of information to be reported in the annual reports of Malaysian SIRCs. Within the purview of public accountability, every citizen has a right to information about government entities, including SIRCs. As such, to support the present study in addition to responding to several calls concerning the discharge of public accountability through reporting (Siraj, 2012; Yasmin et al., 2014; Steccolini, 2004; Pollitt, 2006; Odainkey \& Simpson, 2013; Tooley et al., 2010), this study used an on line questionnaire survey in which respondents was given a list of disclosure items to indicate their weighted importance (ranging from $1=$ not important to $5=$ extremely important) for each item. There were 57 items tested (based on the pilot survey) under five categories of information, these are: corporate (Cl); strategic (SI); financial performance (FP); non-financial performance (NFP); and financial statements (FS). The responses were analysed based on their type of stakeholder group, i.e. either internal SIRC members or external stakeholders. The former were classified into three employment levels, namely: top officials; management; and support staff, whereas the latter included regulators, the public and creditors. Such classifications are important to see any significant differences between the sub-stakeholder groups in their expectations of each disclosure item, which may usefully be reconciled towards satisfying the numerous needs of users of annual reports.

In sum, all of the disclosure items by category were regarded as very important by all of the stakeholders. There was no significant difference between internal and external stakeholders' expectations in the category of information of the SIRCs' annual reports. Nevertheless, that result was different when comparing every single item in each category except $\mathrm{Cl}$ and FS. There were eight items with statistically significant differences between internal and external stakeholders in three categories, namely: SI (2) - summary facts and figures and government grants; FP (3) - ratios in rental income, investment income and income by activities; NFP (3) - indicators of effectiveness, productivity and customer satisfactions. The internal and external stakeholders had similar expectations of the level of importance of the corporate and financial statement items, while others were quite variable.

In particular, there were seven items viewed as quite important by either internal (SIRCs) or both group of stakeholders. The SIRCs themselves perceived government grants (SI), productivity measure (NF) and financial ratios such as rental income (FP), investment (FP) to be quite important, and both groups of stakeholders saw chairman statement (SI), personnel and personnel development $(\mathrm{Cl})$ item as quite important. All FS items were treated as very important by all stakeholders. It was found that SIRCs had less interest in a few items concerned with performance reporting compared with the financial performance report beyond what is given in the traditional financial statement. This may have contributed to the content of reporting, which was heavily influenced by the routine financial statements. Not surprisingly, there have been several inquiries on the accountability of the SIRCs due to their lack of information dissemination (Wahid et al., 2009). In fact this study found that external stakeholders had greater expectations of the SIRCs' annual reports than internal stakeholders, which may raise an issue of accountability discharge among SIRCs.

The analysis of sub-stakeholders was further investigated to understand their needs so as to reconcile the weighted of importance for each disclosure item. Strategic information was the only significant difference of information category across sub-stakeholders. However, comparing the means for each disclosure item in each category, shows that there were 13 items with significant differences in every category, these were: $\mathrm{Cl}(2)$ - objective and 
organisational structure, SI (2) - chairman statement and government grant, FP (2) investment and actual to budget comparison, NFP (3) - objective/performance target, outcome and efficiency and FS (4) - long-term investment, deferred liabilities, deferred government credit and balance b/f. Detailed mean scores were analysed to identify such differences. On average, support staff regarded $\mathrm{Cl}$ and NFP as being quite important, while $\mathrm{Cl}$ was similarly regarded by management and creditors. This indicates that low level employees of SIRCs were possibly not aware the importance of reporting for the discharge of public accountability responsibilities other than mandatory financial reporting. However, $\mathrm{Cl}$ was seen as less important to creditors, probably due to their concern with solvency (Tooley et al., 2010) rather than background information about SIRCs.

An issue of voluntary disclosure of information other than financial statements is believed to have contributed to the lack of awareness on comprehensive disclosure information. For that reason, more than half of the NFP items had different expectations across the stakeholders as compared to a quarter of the FS items. This supports a notion that regulations greatly influence the perceptions of users and disclosure practices accordingly. Although there was no significant difference between internal and external stakeholders in FS and $\mathrm{Cl}$, comparing sub-stakeholders result to different findings. Indeed, a thorough analysis of the needs of each individual stakeholder is essential. A M-W test comparing pairs of stakeholder groups was conducted to summarise the differences and similarities of number of disclosure items between category of information. It was found that within SIRCs, top officials and support staff had significant difference, a similar result was found for support staff and creditors. In comparing with creditors, the public and regulators have more interest in knowing about the accountability of SIRCs in accordance to their purpose of establishment. Likewise, top officials favour more disclosure for their political competitions (Laswad et al., 2005) as compared to support staff or employees as a whole who can affect and affected by the actions and decisions (Freeman, 1984) being made by SIRCs in terms of financial and non-financial benefits for them. The expectation gaps between powerful and disadvantaged stakeholders should be harmonised to produce a good practice of reporting for SIRCs.

The present study, however, is subject to a few limitations. Remarkably, although the response rate was acceptable of $36 \%$ and it covers all the SIRCs throughout Malaysia, the number of response rate for each sub-stakeholder might be interpreted with caution due to localisation of certain sub-groups of stakeholders. Both response rate of SIRCs support staff and creditors were less than $10 \%$, and should be regarded as disadvantaged stakeholders. However, excluding them indeed from this study might have meant it was not pertinent in promoting the notion of public accountability. Due to different size of SIRCs in terms of their funding or specifically of zakat collection, the stakeholders can be expected to have different interests. As such, this would be pertinent to be considered in future research.

As SIRCs are faith-based organisations, accountability should be better portrayed to increase trust among the community at large. Trust is not an easy quality to achieve without the appropriate mechanism to discharge accountability. This study infers that external stakeholders perceived a higher importance of disclosure in the SIRCs' annual reports than the SIRCs themselves. An application of weighted importance of disclosure items can be used to evaluate the extent of reporting practices among SIRCs. A wide range of stakeholders, especially SIRCs themselves, are able to judge whether the SIRCs' current reporting is adequate against the stakeholders' expectations. This result also might be of interest to the powerful stakeholders such as SIRCs' top officials and regulators. It 
would be useful to research the reasons for their expectations to account for the different point of views between powerful and less privileged stakeholders. This might be useful to the report preparers to consider in preparing the reports while identifying their problems to produce the best practice of annual report, so as to be the ideal mechanism for discharging the accountability responsibilities of the reporting entities. As such, this does not apply just to SIRCs but it might be pertinent to other related organisations such as faith-based organisations, NPOs, charities and governmental entities.

\section{References}

Abdul-Rahman, AR and Goddard, A 2003. Accountability Verstehen: A Study of Accounting in State Religious Councils in Malaysia, Discussion Paper, University of Southampton, United Kingdom.

Abdul-Rahman, AR and Goddard, A 1998. An interpretive inquiry of Accounting practices in religious organisations, Financial Accountability \& Management, Vol.14, No.3, pp. 183-201.

Afifuddin, HB and Siti-Nabiha, AK 2010. Towards good accountability: The role of Accounting in Islamic Religious Organisations, World Academy of Science, Engineering and Technology, Vol.66, pp.1133-1139.

Belkoui, AR 2004. Accounting Theory, 5th ed., London: Thompson.

Brammer, S and Millington, A 2004. The development of corporate charitable contributions in the UK: A stakeholder analysis, Journal of Management Studies, Vol.41, No.8, pp.1411-1434.

Broadbent, $J$ and Guthrie, $J$ 1992. Changes in the public sector: A review of recent 'alternative' Accounting research, Accounting, Auditing \& Accountability Journal, Vol.5, No.2, pp.3-31.

Coy, D, Fischer, M and Gordon, T 2001. Public accountability: A new paradigm for college and university annual reports, Critical Perspectives on Accounting, Vol.12, No.1, pp.131.

Dhanani, A and Connolly, C 2012. Discharging not-for-profit accountability: UK charities and public discourse, Accounting, Auditing \& Accountability Journal, Vol.25, No.7, pp.1140-1169.

Freeman, RE 1984. Strategic Management: A Stakeholder Approach, Boston: Pitman.

Gray, A. and Jenkins, B 1993. Codes of accountability in the new public sector, Accounting, Auditing \& Accountability Journal, Vol.6, No.3, pp.52-67.

Grosso, AL and Van Ryzin, GG 2012. How citizens view government performance reporting, Public Performance \& Management Review, Vol.35, No.2, pp.235-250.

Haque, MS 2007. Revisiting the new public management, Public Administration Review, Vol.67, No.1, pp.179-182. 
Heijden, HVD 2013. Small is beautiful?: Financial efficiency of small fundraising charities, The British Accounting Review, Vol.45, No.1, pp.50-57.

Hisham, Y 2006. Waqf Accounting in Malaysian State Islamic Religious Institutions (SIRC): The Case of Federal Territory SIRC, Unpublished Masters Dissertation, International Islamic University of Malaysia, Malaysia.

Hooks, J, Tooley, S and Basnan, N 2012. An index of best practice performance reporting for Malaysian local authorities, Journal of Applied Accounting Research, Vol.13, No.3, pp.270-283.

Hoque, Z and Moll, J 2001. Public sector reform, The International Journal of Public Sector Management, Vol.14, No.4, pp.304-326.

Horner, L, Lekhi, R and Blaug, R 2006. Deliberative Democracy and The Role of Public Managers, London: The Work Foundation, London.

Hyndman, N 1990. Charity Accounting: An empirical study of the information needs of contributors to UK fund raising charities, Financial Accountability and Management, Vol.6, No.4, pp.295-307.

Hyndman, N 1991. Contributors to charities: A comparison of their information needs and the perceptions of such by the provides of information, Financial Accountability \& Management, Vol.7, No.2, pp.69-82.

Mohamed Ibrahim, SH 2000. The need for Islamic Accounting, Perceptions of Its Objectives and Characteristics by Malaysian Muslim Accountants and Accounting Academics, Unpublished Ph.D Dissertation, University of Dundee, United Kingdom.

Khumawala, SB, Parsons, LM and Gordon, TP 2003. Assessing the quality of not-for-profit efficiency ratios: Do donors use joint cost allocation disclosures?, Journal of Accounting, Auditing \& Finance, Vol.20, No.3, pp.287-310.

Laswad, F, Fisher, R and Oyelere, P 2005. Determinants of voluntary internet financial reporting by local government authorities. Journal of Accounting and Public Policy, Vol.24, No.2, pp.101-121.

Lee, M 2004. Public reporting: A neglected aspect of nonprofit accountability. NonProfit Management \& Leadership, Vol.15, No.2, pp.169-185.

Odainkey, HN and Simpson, SNY 2013. Ensuring accountability in state-owned enterprises: Examining the role of annual reports from a middle income country's perspective, The Journal of Institute of Public Enterprise, Vol.36, No.1\&2, pp.1-20.

Pollitt, C., 2006. Performance information for democracy: The missing link?, Evaluation, Vol.12, No.38, pp.38-55.

Romzek, BS 2000. Dynamics of public sector accountability in an era of reform, International Review of Administrative Sciences, Vol.66, No.1, pp.21-44. 
Hyndman, $\mathrm{N}$ and Anderson R 1995. The use of performance information in external reporting: An empirical study of UK executive agencies. Financial Accountability \& Management, Vol.11, No.1, pp.1-17.

Siraj, SA 2012. An Empirical Investigation into The Accounting, Accountability and Effectiveness of Waqaf Management in the State Islamic Religious Councils (SIRCs) in Malaysia. Unpublished Ph.D Dissertation, Cardiff University, United Kingdom.

Siti-Rokyah, MZ 2005. Determinants of Financial Reporting Practices on Waqf by State Islamic Religious Councils in Malaysia, Unpublished Masters Dissertation, International Islamic University of Malaysia, Malaysia.

Steccolini, I 2004. Is the annual report an accountability medium?: An empirical investigation into Italian local governments, Financial Accountability \& Management, Vol.20, No.3, pp.327-350.

Sulaiman, M, Adnan, MA and Nor, PNSMM 2009. Trust Me!: A case study of the International Islamic University Malaysia 's Waqf Fund. Review of Islamic Economics, Vol.13, No.1, pp.69-88.

Tooley, S, Hooks, J and Basnan, N 2010. Performance reporting by Malaysian local authorities: Identifying stakeholder needs. Financial Accountability \& Management, Vol.26, No.2, pp.103-133.

Wahab, NA and Abdul-Rahman, AR 2011. 'Efficiency of zakat institutions and its determinants', In: Proceedings of the 8th International Conference on Islamic Economics and Finance, pp.1-19.

Wahid, H, Ahmad, S and Kader, RA 2009. Pengagihan zakat oleh institusi zakat di Malaysia: Mengapa masyarakat Islam tidak berpuas hati?, Jurnal Syariah, Vol.17, No.1, pp.89-112.

Yaacob, H. and Nahar, HS 2011. Accounting and accountability in the sacred context: The case of management, accounting and reporting of a Malaysian cash awqaf institution, Journal of Islamic Accounting and Business Research, Vol.2, No.2, pp.87-113.

Yasmin, S, Haniffa, R and Hudaib, M 2014. Communicated accountability by faith-based charity organisations, Journal of Business Ethics, Vol.122, No.1, pp.103-123. 